\title{
АКТУАЛЬНІ ПИТАННЯ ВИКЛАДАННЯ ФАРМАКОЛОГІЇ НА МЕДИЧНОМУ ТА СТОМАТОЛОГІЧНОМУ ФАКУЛЬТЕТАХ: ПРОБЛЕМИ ТА ПЕРСПЕКТИВИ
}

\author{
Н. І. Волощук, О. С. Пашинська, Е. В. Белясв \\ Вінницький національний медичний університет імені М. I. Пирогова
}

\section{BASIC QUESTIONS OF THE TEACHING OF PHARMACOLOGY FOR STUDENTS OF MEDICAL AND STOMATOLOGY FACULTIES: PROBLEMS AND PERSPECTIVES}

\author{
N. I. Voloshchuk, O. S. Pashynska, E. V. Beliayev \\ Vinnytsia National Medical University by M. I. Pyrohov
}

\begin{abstract}
У статті розглянуто основні принципи побудови навчального процесу на кафедрі фармакологї, основні питання $\mathbf{i}$ проблеми викладання предмета для студентів медичного та стоматологічного факультетів за умов кредитно-модульної системи.
\end{abstract}

In article main principles of construction of education process on pharmacology department, the basic questions and problems of the teaching at medical and stomatological faculties according to the principles of credit-modular system are considered.

Вступ. Розвиток в Україні процесу підготовки фахівців за кредитно-модульною системою, а також розпочата в нашій країні реформа медичної галузі стимулюють вітчизняну вищу школу до проведення відповідних реформ $[1,2]$. На основі сформульованих у державних стандартах професійно-освітніх вимог у ВНЗ визначаються цілі і зміст підготовки спеціалістів, розробляються навчальні плани і програми, визначається методика проведення занять, встановлюються критерії якості підготовки студентів на різних етапах навчання $[3,4]$. Водночас всі зусилля викладацього складу, особливо в медичних закладах, спрямовані на те, щоб у процесі інтегрування в Європейський простір не втратити ті надбання та здобутки, якими завжди пишалась вітчизняна вища школа. 3 іншого боку, наша сучасність вимагає зміни застарілих методичних підходів, адекватного використання науково-технічного прогресу.

Основна частина. Впровадження Болонської системи викладання в медичних вузах України, в тому числі і у Вінницькому медичному університеті на медичному факультеті, проводиться вже п'ять років. За цей час викладачі вже змогли оцінити всі переваги такої системи, а також недоліки, та певним чином пристосувати кредитно-модульне викладання до особливостей і потреб національної системи охорони здоров'я.
Викладання фармакології відповідно до вимог кредитно-модульної системи має свої особливості. Перш за все, була необхідність у створенні нової навчальної програми з фармакології, яка б давала змогу належним чином поєднати базові знання, яких набувають студенти під час слухання лекцій та підготовки до практичних занять, із самостійною та індивідуальною роботою, які складають значну частину в роботі студентів. Така програма була розроблена на базі “опорної” кафедри фармакології НМУ ім. О. О. Богомольця (зав. каф. - чл.-кор. НАН та АМНУ, проф. I. С. Чекман) у 2006 році. Протягом 2006-2007 рр. група викладачів фармакології різних вузів України на сумісних засіданнях обговорювала основні шляхи викладання фармакології відповідно до нових вимог та працювала над розробкою методичних рекомендацій для самопідготовки студентів.

На основі типової програми кафедрами були розроблені робочі навчальні програми, які враховували кількість лекцій, практичних занять та обсяг самостійної роботи студентів. Курс фармакологї вміщував 3 модулі. Підсумковий модульний контроль (ПМК) включав в себе як теоретичну частину, зокрема теоретичні питання і комп'ютерне тестування за допомогою завдань “Крок-1”, так і практичну частину, а саме виписування рецептів та вирішення фармакотерапевичних задач II та III рівнів. 
Медичний ліцензійний іспит (МЛI) "Крок" - невід'ємна складова навчання у медичному вузі. Одним 3 найбільш важливих та складних етапів цього тестування є “КРОК-1". В цей іспит входить 9 предметів, які вивчаються студентами на першому, другому та третьому курсах. Обсяг матеріалу з кожного предмета $є$ досить великим, тому за час, який відводиться для підготовки до екзамену, студентам складно повторити весь необхідний матеріал. Наразі банк тестових завдань “Крок-1" з фармакології містить більше 700 задач з різних розділів фармакології. Під час навчального року викладачі розбирають та вирішують зі студентами найбільш типові задачі з кожної теми. Але, як показав більш як 10-річний досвід результатів складання МЛІ “Крок-1”, цього виявляється недостатньо. Це зумовлено, на нашу думку, досить об'єктивними причинами, зокрема тим, що в Україні, як і у всьому світі, кількість нових лікарських засобів, які з'являються на фармацевтичному ринку, зростає з кожним роком. Це зумовлює постійне поповнення та поновлення переліку найменувань препаратів, що входять до програми навчання в медичному вузі, а отже, і в тестуванні. Крім того, стає дедалі глибшим розуміння тонких механізмів дії лікарських препаратів, і як наслідок - кількість і складність тестів 3 фармакології, які входять до МЛІ “Крок-1”, зростає. Для покращення засвоєння та запам'ятовування тестових задач на кафедрі фармакології ВНМУ були впроваджені такі заходи:

- банк тестових завдань “Крок-1” перекладено на російську та англійську мову, існує в паперовому та електронному варіантах, він $є$ доступним для студента, про що наголошується з перших занять на кафедрі; - всі тести розділені на 5 розділів відповідно до тем підсумкових занять. Кожний з них включає близько
130-140 завдань, які, в свою чергу, розподілені на окремі теми згідно з навчальним планом;

- обов'язковою складовою частиною кожного підсумкового заняття під час вивчення фармакології, а також при ПМК, є складання тестів на комп'ютері. Студент відповідає на 15 (підсумкові заняття) або 35-40 (ПМК) запитань, які вибираються комп'ютером для кожного студента. Порядок відповідей у тесті кожний раз змінюється. В кінці тестування програма показує кількість правильних та неправильних відповідей і загальну оцінку за тест.

Таким чином, впровадження комп'ютерних програм у вивчення фармакології:

- дає можливість використання новітніх технологій у вивчення предмета;

- збагачує студента необхідним досвідом, адаптує до роботи з комп'ютером;

- розвиває швидкість реакції та мислення, надає впевненості при проходженні комп'ютерного тестування на наступних етапах становлення і професійного росту;

- створює передумови для уніфікованої та стандартизованої оцінки знань студентів, зменшує ступінь суб'єктивізму в оцінюванні й полегшує роботу викладача [5].

На відміну від медичного факультету, викладання фармакології відповідно до вимог кредитно-модульної системи для студентів-стоматологів розпочалось тільки в 2011-2012 навчальному році. Набутий досвід дозволив відразу включитись в цю систему, уникнути помилок та недоліків, що мали місце на початку викладання за новими вимогами. Однак при впровадженні такої системи на стоматологічному факультеті слід було враховувати деякі особливості (табл. 1).

Таблиця 1. Основні відмінності в розподілі навчальних годин між медичним та стоматологічним факультетами

\begin{tabular}{|l|c|c|}
\hline \multicolumn{1}{|c|}{ Особливості навчального плану } & Медичний факультет & Стоматологічний факультет \\
\hline Курс, на якому вивчається предмет & 3 & $2-3$ \\
\hline Загальна кількість годин для вивчення дисципліни & 210 & 165 \\
\hline Кількість лекційних годин за рік (по семестрах) & $40(20 / 20)$ & $20(10 / 10)$ \\
\hline $\begin{array}{l}\text { Кількість годин для аудиторних занять за рік (по } \\
\text { семестрах) }\end{array}$ & $90(40 / 50)$ & $100(50 / 50)$ \\
\hline $\begin{array}{l}\text { Кількість годин для позааудиторної самостійної } \\
\text { роботи }\end{array}$ & 80 & 45 \\
\hline
\end{tabular}

До найбільш вагомих слід віднести те, що предмет “Фармакологія" починає викладатись над другому курсі (IV семестр), коли у студентів-стоматологів відсутні навіть початкові знання з клінічних дисциплін. Вони не в повній мірі володіють медичною термінологією, погано розуміють сутність захворювань, а тому їм дуже важко зрозуміти показання, протипоказання та побічні ефекти багатьох лікарських засобів. Крім того, у майбутніх стоматологів дуже слабка мотивація до вивчення лікарських засобів деяких фармакологічних груп, таких, як, наприклад, нейролептики, транквілізатори, інші психотропні засоби, антихолінестеразні 
препарати тощо. Ще однією суттєвою відмінністю є дуже мала кількість лекційних годин порівняно $з$ медичним факультетом. Тому викладач віддає перевагу оглядовим лекціям, практично не зупиняється на окремих групах та лікарських препаратах. Реальним шляхом для подолання цих складнощів є взаємодія та співпраця студента з викладачем під час практичного заняття, коли викладач враховує особливості характеристики студентів, психологічне та емоційне налаштування на предмет, що вивчається, може пояснити незрозумілі питання. Водночас пріоритет слід віддавати діалоговому (полілоговому, розвиваючому) навчанню над монологовим, залучення до цього новітніх інноваційних методологій викладання (мозковий штурм, рольові ігри тощо). Тут на перше місце виходять фармакотерапевтичні та ситуаційні задачі, які стосуються проблем, що можуть виникнути “біля ліжка хворого”, або “біля стоматологічного крісла". Рішення цих задач самостійно чи разом з викладачем не тільки полегшує процес запам'ятовування матеріалу, але і показує конкретні точки прикладання набутих знань у клінічних умовах [6]. Безумовно, така практика вимагає усвідомлених та сумлінних дій викладача, які можуть бути результатом їх високої професійної та психолого-педагогічної компетентності. Професорсько-викладацький склад кафедри постійно контактує з викладачами кафедр стоматологічного профілю. Сумісні методичні наради дозволяють більше уваги звертати на найбільш поширені препарати, розробляти клінічні задачі, створювати адекватні клінічні ситуації.

Нами були внесені також корективи до кількості та форми проведення підсумкових модульних контролів. 3'ясувалось, що велика кількість ПМК вимагає великої кількості навчальної документації, супроводжується тривалим багаторазовим перескладанням, що є незручним як для викладачів, так і для студентів. Врахувавши ці моменти, на сумісному засіданні завідувачів кафедр фармакології медвузів України було погоджено оптимальну кількість модульних занять 3 фармакології для медичного та стоматологічного факультетів - 2. Перший модуль включає “Загальна фармакологія. Фармакологія засобів, що впливають на центральну та периферичну нервову систему”. Другий модуль “Фармакологія засобів, що впливають на виконавчі органи. Засоби для боротьби зі збудниками інфекційних хвороб”. За розподілом тем ці модулі припадають на кінець навчальних семестрів, вони є логічним їх завершенням.

Однак слід відмітити, що однією з проблем при підготовці до модульних занять для студентів є про- ведення їх у мережі занять, відсутність достатнього часу для належної підготовки. Крім того, інколи студентам в один день припадає декілька модулів, що негативно відбивається на процесі підготовки, і, відповідно, результатах складання. Тому нами було виділено 4 навчальних години (два заняття) для складання ПМК. На першому студенти складають комп'ютерний тестовий контроль “Крок-1”, а також вирішують фармакотерапевтичні задачі та виписують відповіді у вигляді рецептів. На другому занятті студент демонструє теоретичну підготовку. Воно побудоване за принципом екзамену. Така можливість “усної бесіди” значно підвищила “авторитет” ПМК 3 фармакологіі, студенти більш сумлінно готуються до модуля, а під час бесіди намагаються продемонструвати не тільки знання з окремих питань, але i певне клінічне мислення.

Ще одним позитивним моментом нових методичних підходів до викладання теоретичних дисциплін, $\mathrm{i}$, зокрема, фармакологіі, як на медичному, так і на стоматологічному факультетах, $\epsilon$ формування у студентів тенденції до самостійної роботи з опанування нового матеріалу, створення здорової конкуренції серед студентської аудиторії [7]. Теми, які виносяться на самостійну підготовку, обов'язково включені до підсумкових модульних контролів, оскільки під час практичних занять немає часу для обговорення цих тем. Водночас нами були створені раціональні умови організації самостійної роботи з урахуванням готовності до неї студентів. Так, окрім плану самостійної роботи, на кафедрі в паперовому та електронному вигляді є сучасні матеріали $з$ тем, що вивчаються, вказується основна та додаткова література, як вітчизняна, так і іноземна. Таким чином, самостійна робота студента є невід'ємною складовою успішного опанування ним фармакології, оскільки тільки ті знання, які людина набула самостійно, завдяки власному досвіду, думці й діям, стають справді ії здобутком.

Висновки: 1. Адаптація кредитно-модульної системи викладання фармакології до вимог національної освіти вимагає ретельної побудови навчального процесу як на медичному, так і на стоматологічному факультетах з врахуванням особливостей розвитку цієї науки у світі, створенням мотивації до вивчення їі майбутніми фахівцями всіх спеціальностей, обов' язковим вирішенням фармакотерапевтичних задач та клінічних ситуацій.

2. Студенту слід не тільки письмово відповідати на питання, розв'язувати тести, але потрібно дати змогу усно висловлювати свою думку, розвивати 
клінічне мислення та професійне мовлення. Необхідним також $є$ детальний розгляд найбільш важливих і погано зрозумілих для студентів питань на практичних заняттях.

3. Прорив України в Європейський освітній простір не може бути пов'язаний із “сліпим” ко-

\section{Лiтература}

1. Болонський процес у фактах і документах / [М. Ф. Степко, Я. Я. Болюбаш, В. Д. Шинкарук та ін.]. - Тернопіль : Вид-во ТДПУ ім. В. Гнатюка, 2003. - 52 с.

2. Товажнянський Л. Л. Болонський процес : цикли, ступені, кредити / Л. Л. Товажнянський, Є. І. Сокол, Б. В. Клименко. - Харків : НТУ “ХПІ”, 2004. - 144 с.

3. Про проведення педагогічного експерименту щодо запровадження кредитно-модульної системи організації навчального процесу у вищих навчальних закладах III-IV рівнів акредитації : Рішення колегії Міністерства освіти і науки України від 24.04. 2003 р. Протокол № 5/5 - 4.

4. Про впровадження кредитно-модульної системи організації навчального процесу : наказ МОН України піюванням не завжди найкращих принципів. Нам слід більше за все зберегти вітчизняні традиції, адаптувати європейську систему до національних особливостей, щоб не втратити тих переваг, якими традиційно пишається українська медична освіта.

№ 774 від 30.12.2005 p.

5. Мілерян В. С. Медичні основи підготовки і проведення навчальних занять в медичних вузах (методичний посібник) / В. С. Мілерян. -К. : Хрещатик, 2006. -84 с.

6. Косенко К. М. Методичні аспекти формування у студента-стоматолога практичних навичок та умінь / К. М. Косенко // Вісник стоматології. - 2006. - № 3. C. 89-90.

7. Підаєв А. В. Болонський процес в Свропі. Що це таке і чи потрібний він Україні? Чи можлива інтеграція медичної освіти України в Свропейський освітній простір? / А. В. Підаєв, В. Г. Передерій. - Одеса : Одес. держ. мед. ун-т, 2004.- 190 с. 